\title{
Assessment of the financial safety of securities companies in Vietnam
}

\author{
Nguyen Phuong Anh \\ Faculty of Business Administration Hanoi University of Industry, \\ No. 298, Cau Dien Street, Bac Tu Liem District, Hanoi, Vietnam. \\ anhnp@haui.edu.vn
}

\begin{abstract}
The study was carried out to assess the financial safety of securities companies in Vietnam through the CAMEL system and Decision 617/QD-UBCK dated October 9, 2013 of the Chairman of State Security Commission of Vietnam (SSC) on guiding the classification of Vietnamese securities businesses. The study used statistical and data collection methods from financial statements and financial safety ratio reports of 71 securities companies which are the members of Ho Chi Minh Stock Exchange in the period 2013-2019. From there, the author calculated and analyzed the groups of criteria for assessing financial safety of securities companies, including: Capital Adequacy (C); Asset Quality (A); Earnings Power (E) and Liquidity $(\mathrm{L})$. The results showed that the financial safety of most securities companies between 2013 and 2019 has been guaranteed, only a few securities companies have not gained capital adequacy or remained low profitability, causing prolonged business losses. Therefore, the study proposed a number of solutions to ensure financial safety for the system of securities companies in Vietnam.
\end{abstract}

Index Terms-Financial Safety, Securities Company.

\section{INTRODUCTION}

A CHIEVING financial safety is increasingly becoming a vital issue for each country, especially in the context of globalization and economic-financial liberalization taking place as fairly rapidly as today. For the operation of financial institutions in general and securities companies in particular, financial safety is not a completely new concept but has not been fully and systematically studied. In addition, the issue of financial safety for the operation of securities companies has a great influence on the stock market and the investor community. However, the financial safety assurance of the system of Vietnamese securities firms is still weaker than many countries in the region and in the world, which is evidenced by the fact that many securities companies in Vietnam have been discharged from the market due to inability to ensure secure finance and continuous business losses. Therefore, the research is conducted to evaluate the financial safety of securities companies that are members of Ho Chi Minh Stock Exchange over the period of 2013-2019, thereby providing appropriate solutions and proposals to ensure financial safety for securities companies next time.

This research has applied classification regulations for securities firms according to CAMEL standards and Decision No. 617/QD-UBCK dated October 9, 2013 of the SSC. This regulation is issued to classify and evaluate their activities comprehensively, on that basis to aid the SSC in the management and supervision of these businesses' activities. Similar to the versions of the CAMEL system used in other countries around the world, the CAMEL system is used in- ternally by the SSC to monitor securities companies. The results of calculation, evaluation and ranking of securities companies are not publicized in order to keep their internal information confidential and avoid affecting their reputation negatively, maintaining stability for the Vietnamese stock market. In general terms, the SSC also uses the factors which are Capital Adequacy (C); Asset quality (A); Management Quality (M); Earnings Power (E) and Liquidity (L) for the CAMEL system applied to Vietnamese securities firms. Whereas, the group of financial factors including $C$, A, E, L can be calculated according to the data taken from the reviewed or audited financial statements, periodical reports and other financial data. The management quality (M) factor is considered separately because it is difficult to quantify this factor and it mainly relies on qualitative criteria to evaluate. There are internal criteria and securities companies need to provide more information to the SSC. Therefore, in this study, the author only studies the group of financial factors to review their financial safety.

\section{Literature REVIEW}

The securities company is a financial institution providing securities services on the financial market. Therefore, the activities of securities companies also have similarities with financial institutions such as commercial banks typically. Therefore, the author's research on financial safety of securities companies is also based on literature review on financial safety of commercial banks. [8] stated that the financial safety net of a country was the security system of commercial banks, insurance companies and securities companies. This study also built the structure of the financial safety net in accordance with the conditions of Latin American countries. In the study of [1], the authors collected data of 17 banks in Pakistan as of December 2010. On the basis of CAMEL model, the study ranked these banks then assessed the level of financial safety of each bank in the research period. Furthermore, the study by [6] also assessed the level of financial safety and the soundness of the Indian banking system according to the CAMEL model comprising of two groups of state-owned banks and private banks. The used research data was the statistics of banks for 11 years (during the research period from 2000 to 2011). Research results have illustrated that the state-owned banks of India always have a better CAMEL rating than private banks, which means that the financial safety and soundness level of the state-owned banks are always higher than those of private banks. India top state-owned banks have the highest level of 
financial safety and private banks like Union Bank and SBI have the lowest financial safety based on the CAMEL rating. In addition, the authors [12] have studied the importance of the elements constituting the CAMEL system, thereby building the optimal criteria set to assess the level of financial safety of financial institutions. The data used in this study were taken from the income statements of Nigerian banks for the period from 1997 to 2005 . The results of the study indicate that no single factor in the CAMEL system has the capacity of comprehensively evaluating a particular financial institution such as a bank. Therefore, it is necessary to combine factors on certain rates; in other words, to build an optimal rating structure for each element in the CAMEL system.

Thus, the studies on financial safety of commercial banks have been conducted by many authors around the world. Most of the studies have used the CAMEL model to rank and evaluate the financial safety of commercial banks, especially comparing the CAMEL ratings of state-owned banks with private banks. Besides, it is desirable to integrate all factors with certain rates, not just rely on a single factor to review the financial safety of a commercial bank.

It can be seen that there is a wide array of studies on financial safety of commercial banks. However, that of securities companies has still become a less concerned matter to the researchers. Globally, there are several typical studies such as: Research by the International Organization of Securities Commissions [3]. In this study, after assessing the capital's effect on liquidity of securities firms as well as on operational risk, the study concluded that securities firms need to ensure capital adequacy to some extent. Securities firms' capital adequacy depends on each active market and the number of businesses that they participate in. Additionally, there is a study by the International Organization of Securities Commissions [4]. This is a study on capital adequacy ratio, liquidity, and the harmonization of capital and assets of non-banking securities firms in some countries with developed stock markets such as the US, UK, France and Japan.

In Vietnam, there have been very few elaborate and systematic studies on securities firms' financial safety so far. Directly related to this topic, it is possible to mention the scientific research topic at Banking Academy level by [7]. In this topic, the author gives his own view on the safety of the financial system and financial safety of securities companies. The topic also outlines some models currently being used to review the financial safety of financial intermediaries. Four of the five factors of the CAMEL model which are capital, assets, liquidity and earnings were used in Chapter 2 to assess financial safety of Vietnamese securities firms from 2012 to 2014. This is also a group of financial factors of securities companies. Based on the results of analysis and assessment of financial safety of Vietnamese securities companies, the author has built a system of solutions to improve their financial safety. However, in this study, the results have not shown the basic characteristics of financial safety of securities companies and not built a system of criteria for assessing their financial safety. Also, this issue is studied from the perspective of securities companies; therefore, the given solutions are only meaningful for them, any solutions for state management agencies in the financial safety super- vision for securities firms' system haven't been recorded. Moreover, it only mentions the financial safety situation of Vietnamese securities firms from 2012 to 2014, not in later periods. During the stock market fluctuation, this study hasn't updated the changes to provide solutions that can be applied in the near future and oriented to 2030 .

What is more, it is possible to mention the research of [2].Theoretically, the study has clarified the concept, evaluation criteria, characteristics, assessment criteria system, influencing factors, especially the research has shown the lessons on ensuring financial safety of global securities companies and lessons for securities companies in Vietnam. In practical terms, the study has assessed the current situation of financial safety of Vietnamese securities firms between 2012 and 2016 through the evaluation criteria; at the same time, it has classified and assessed the financial safety of Vietnamese securities companies according to the CAMEL model and Circular 226. On that basis, it has proposed solutions to ensure financial safety for securities companies, including solutions for securities firms and for state management agencies. In general, the thesis has clarified the issue of financial safety of Vietnamese securities companies, however, the research period ends in 2016, which is also a gap for further studies to be carried out.

\section{TheORETICAL FRAMEWORK}

\section{A. The concept of financial safety of securities companies}

As stated by Chinese economists, Financial safety refers to the safety of the monetary fund and the stability of the entire financial system [11]. Financial safety is the basic problem studying financial economics. In the rapid development of the current globalized economy, financial safety has played an increasingly enhanced role in national economic security. Financial safety is closely related to the financial crisis. Specifically, safety level may be explained and measured through risk and crisis; on the other hand, financial risk and crisis level may be explained and measured by using financial safety. The higher safety level leads to the lower risk and vice versa. Financial crisis results from a large-scale outbreak of accumulated risks, being a serious insecurity as well as a financial disaster. Thus, financial safety bears a close relevance to financial risk.

As claimed by [2], 'securities firms' financial safety is the state of financial stability and soundness of a securities company, on that basis, minimizing risks for securities companies". Financial stability means that there are no abnormal fluctuations while creating, distributing and using monetary funds and financial relationships of securities companies. Financial stability plays an essential role in the development of securities firms. A securities company with financial instability will be vulnerable to the crisis. However, it is necessary to maintain stability in the movement and development. It not only needs to maintain financial activities as in previous years but must always be in the process of going up, further improving operational efficiency and constantly developing. In other words, financial stability must always be associated with financial soundness. The financial soundness of securities firms is initially a condition in which the securities firms effectively perform their inherent functions 
for the economy and simultaneously have the ability to curb or handle risks in advance of those threats to the operation of securities companies. More specifically, if considered in a narrow scope, the financial soundness of a securities company is a condition in which the assets and capital sources do not fluctuate abnormally, meet debt obligations and risks, are not crisis-free and also expressed by its state of financial stability. The sustainable financial status is reflected in the fact that the securities company can meet enough business capital, ensure asset quality, meet the requirements of profitability and liquidity, and improve the quality of corporate governance.

Accordingly, financial safety of securities firms can also be defined as a state of being free from danger or threat from internal and external influences. In other words, the activities associated with the assets and capital of the securities company are not left vulnerable from the risks during their business activities.

\section{B. Assessment criteria for financial safety of securities companies}

To evaluate the financial safety of securities companies, the author relies on the table of criteria, scale and weight of financial factors in the ranking of securities companies shown in Appendix 01 issued with Decision No. 617/ QD. /UBCK dated October 9, 2013 of the Chairman of the State Securities Commission. However, agreeing with the authors of the study [7] and [10], the author also believes that the criteria group of management quality $(\mathrm{M})$ is only a factor affecting the financial safety of securities firms. Hence, the author will employ the CAMEL criteria set selectively, using only 4 groups of financial criteria of this set including: Capital adequacy (C), Asset quality (A), Earnings power (E), Liquidity (L). This set of criteria is called the CAEL model to assess the financial safety levels. At the same time, in each group of indicators, the author selects a representative one (with high evaluation weight in the group) to include in the set of criteria for assessing financial safety of securities companies. Specifically, the evaluation criteria used in the study include:

1. Available fund ratio (belonging to the criteria group of Capital Adequacy - C)

$$
\text { Available fund ratio }=\frac{\text { Available funds }}{\text { Total risk value }}
$$

Available capital ratio is an important indicator in assessing the capital adequacy of financial institutions in general and securities companies in particular. This indicator is used by most of the studies; typically, studies [2], [3], [4], [7] used available capital ratio in the set of criteria for assessing the financial safety of securities firms.

Available funds are the amount of capital that is accessible to meet financial obligations. It can be known as the equity that can be converted into cash in a short period of time. It is usually calculated by subtracting illiquid asset value from equity. What items will be excluded in determining available funds will depend on each country's regulations and each stage of the market.

Total value at risk is the total value of market risk, liquidity risk and operational risk. Market risk value corresponds to the level of loss that can occur when the market price of the asset in possession fluctuates in an adverse direction. Value at liquidity risk is the value corresponding to the level of loss that can occur when the counterparty is unable to make payment on time or fails to deliver assets on time as committed. Value at operational risk refers to the level of losses incurred for technical errors, systems and failed operational processes, human errors in the operation process, or due to lack of business capital arising from investment expenses and losses, or from other external events.

The efficiency level in ensuring financial safety of securities companies is demonstrated through the continuity of the process of ensuring the available capital adequacy ratio when always meeting the requirements of capital adequacy, operational safety, and not falling into a state of being controlled or special control as required by law.

2. Ratio of receivables/total assets (belonging to the criteria group of Asset Quality - A)

Accounts Receivables

Ratio of receivables/total assets $=$

Total assets

This indicator has a weight of $10 \%$, which is high compared to the rest of the indicators of asset quality, so this is also very important in assessing the financial safety of securities firms. It has been used by studies [2] and [7] to evaluate the financial safety of securities companies.

If this ratio is high, most of the securities company's assets are used to finance customers. Thus, the asset safety level will rely on the financial situation as well as the variations in the customer's investment portfolio. It will be difficult for the securities firms to control the risks. As a consequence, the laws of many countries often give a maximum rate for this criterion to ensure the safety of the securities firm's assets.

(3) Return on Equity - ROE (belonging to Earnings indicators - E)

$$
\text { ROE }=\frac{\text { Net Income }}{\text { Shareholders' Equity }}
$$

ROE is a very common indicator in assessing the earnings power of enterprises generally and securities companies particularly. ROE is also an indicator that investors are very interested in when analyzing and evaluating the financial situation of a business. This is also applied by studies [2] and [7] to evaluate the financial safety of securities companies.

Return on Equity is a measure of profitability that calculates how many dollars of a profit a company generates with each dollar of shareholders' equity. This measure signifies all aspects of financial management, including revenue and expense management, asset management, and capital management of securities companies. The higher this ratio is, the more effectively the securities firms' equity is used, which is the basis for them to increase their capital size as well as ensure their financial safety.

(4) Short-term assets to short-term debt ratio (in the group of liquidity $-L$ )

It is also known as the short-term debt ratio. This ratio indicates the likelihood that a company will be able to deliver payments on its outstanding short-term liabilities, so it also shows the level of security for short-term debt payments of the securities company. 


\section{Short-term debt ratio $=\frac{\text { Short-term assets }}{\text { Short-term liabilities }}$}

This indicator has a weight of $15 \%$, the highest in the group of indicators to assess the liquidity quality of securities companies, proving that this criterion is very essential in assessing the financial safety of securities businesses. This indicator has been used by studies [2] and [7] to evaluate the financial safety of securities companies.

On the whole, the low ratio (especially ratios less than one) suggests that the company may be incapable of making debt payments and it is also a sign of potential financial difficulties that a securities firm may encounter in making payments on its short-term debts. On the other hand, this greater coefficient reflects that the company will be able to be ready to pay short-term debts that are due and then it will help the firm to maintain financial safety in its business activities.

\section{Research Method}

The research method primarily used in the study is qualitative method, specifically including the following variants:

- Statistical method: Data are collected and synthesized from financial statements and reports on financial safety ratio of 71 securities companies that are members of $\mathrm{Ho} \mathrm{Chi}$ Minh Stock Exchange over the period 2013-2019 to serve the assessment of financial safety of the securities company system in Vietnam. The source of research data is taken from the information page of Ho Chi Minh Stock Exchange (hsx.vn).

- Method of analysis, comparison and evaluation: On the basis of analyzing every specific criterion, the researcher compares them over the years and makes assessments on capital adequacy (C), asset quality (A), earnings (E) and liquidity (L) of securities firms, thereby giving a general review of their financial safety.

\section{Assessment of Financial Safety of Vietnamese Securities} CORPORATIONS

\section{A. Assess capital adequacy (C)}

As previously mentioned in the section of assessment criteria, the indicator of available funding ratio is chosen to evaluate the capital adequacy of the securities company. Their average ratio of available capital for the period of 2013-2019 is demonstrated in the following chart:

Unit: \%

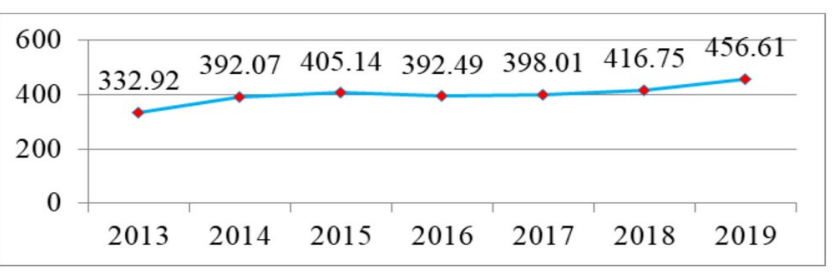

Figure 1. Average available capital ratio of securities companies from 2013 to 2019

(Source: compiled from the financial statements of the member securities firms of Ho Chi Minh Stock Exchange)

It is noticeable that the ratio had a tendency to increase gradually over the period (only slightly decreased in 2016 and 2017). At the same time, the number of securities companies that do not meet this safety criterion also decreased. The main reason is that the restructuring process of securities companies has been carried out since 2012, which has helped these businesses increasingly ensure capital safety. According to Circular 91/2020/TT-BTC dated November 13,2020 , which stipulates financial safety norms and measures for handling securities organizations that do not meet financial safety targets [5] and rating criteria for securities firms according to Decision 617 [9], those with the available capital ratio of less than $180 \%$ are considered the unsound, including:

Table 1. Securities companies (SC) with unsecured available capital ratio $(<180 \%) U_{N I T:} \%$

\begin{tabular}{|c|c|c|c|c|c|c|c|c|c|c|}
\hline \multirow{2}{*}{} & \multicolumn{2}{|c|}{$\mathbf{2 0 1 3}$} & \multicolumn{2}{c|}{$\mathbf{2 0 1 4}$} & \multicolumn{2}{c|}{$\mathbf{2 0 1 5}$} & \multicolumn{2}{c|}{$\mathbf{2 0 1 6}$} & \multicolumn{2}{|c|}{2019} \\
\cline { 2 - 12 } & SC & Ratio & SC & Ratio & SC & Ratio & SC & Ratio & SC & Ratio \\
\hline $\mathbf{1}$ & ART & 48 & SBS & 16.54 & VICS & 156.42 & ORS & 150.16 & CVS & 136.2 \\
\hline $\mathbf{2}$ & BSI & 154 & SBBS & 149 & & & & & VICS & 151.8 \\
\hline $\mathbf{3}$ & ABS & 167.52 & BSI & 166 & & & & & & \\
\hline $\mathbf{4}$ & PHS & 173 & MSC & 168.7 & & & & & & \\
\hline $\mathbf{5}$ & ORS & 179 & BSC & 171 & & & & & & \\
\hline
\end{tabular}

(Source: compiled from the financial statements of the member securities companies of Ho Chi Minh Stock Exchange)

It is immediately apparent that the number of securities companies with an unsecured ratio of available capital was 5 in 2013 and 2014 (accounting for $7.04 \%$ of the total number of securities companies). In particular, SBS Securities Company has a very low rate of available capital in the year 2014 , constituting only $16.54 \%$, while the financial safety level must be over $180 \%$. Similarly, the figure for ART Securities Company in 2013 was also low, at $48 \%$. In contrast, from the 2015's onwards, these two corporates were excluded from those with an unsecured available capital ratio, which were VISC in 2015 and ORS in 2016. Over the next two years, no securities firms had to experience the ratio below $180 \%$. However, by the end of 2019, VICS Securities Company continued to have an unsecured capital ratio, compared to CVS with a rate of $136.2 \%$. It can be observed that the number of securities companies that do not meet the criteria has decreased compared to the pre-restructuring period (before 2012). That proves during the restructuring of securities companies, weak companies which do not meet the requirements of the available capital ratio have been purged from the market. Most of the securities companies currently operating in the market meet the requirements for the available capital ratio.

\section{B. Access Asset Quality (A)}

The financial safety of securities organizations depends a lot on the ratio of receivables to their total assets. If this ratio is getting higher, the financial safety level will depend much on receivables. Therefore, to ensure financial safety for these firms, the ratio of receivables to total assets will have to be limited at a certain rate, which is currently applied to Vietnamese securities companies at $50 \%$. With this figure, securities companies will be less reliant on receivables, then finance will be more secure. 
Unit: \% October 9, 2013, those with ROE at $5 \%$ or more are consid-

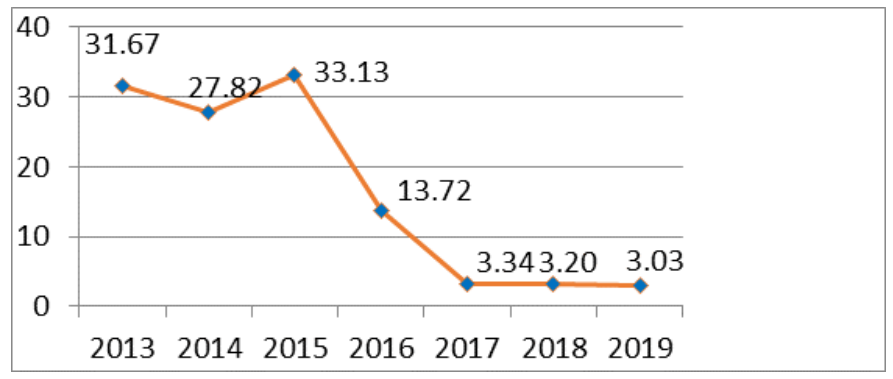

Figure 2. Receivables to total assets ratio of securities companies (Source: compiled from financial statements of member securities companies of Ho Chi Minh Stock Exchange)

It can be seen from the graph that the receivables to total asset ratio has a downward trend over the period shown and is at a very low level in the last 3 years (over $3 \%$ ). The rate in previous years were also below $50 \%$. Thus, it can be inferred that the ratio of receivables to total assets averaged for 71 member securities companies of Ho Chi Minh Stock Exchange in the period 2013-2019 is safe. That has proven that the securities companies have more closely managed the receivables in total assets to limit the risks associated with doubtful debts, or irrecoverable debts. However, some of them underwent a quite high rate (over 75\%), which was seen by SJCS Securities Company in 2013 at $85.29 \%$ and SBSI and KIS in 2015 at over 79\%. In 2014, 2016, 2017 and 2018 there was no securities company with this ratio above $75 \%$. In 2019 , only VNCS had this ratio of $84 \%$. Details are shown in Table 2 below:

Table 2. Securities companies with a Ratio of receivables to total assets OVER $75 \%$ UNIT: \%

\begin{tabular}{|c|c|c|c|c|c|c|}
\hline \multirow{2}{*}{ No } & \multicolumn{2}{|c|}{$\mathbf{2 0 1 3}$} & \multicolumn{2}{|c|}{2015} & \multicolumn{2}{|c|}{2019} \\
\cline { 2 - 7 } & SC & $\begin{array}{c}\text { Receivables } \\
/ \\
\text { total assets }\end{array}$ & SC & $\begin{array}{c}\text { Receivables } \\
/ \\
\text { total assets }\end{array}$ & SC & $\begin{array}{c}\text { Receivables } \\
/ \\
\text { total assets }\end{array}$ \\
\hline $\mathbf{1}$ & $\begin{array}{c}\text { SJC } \\
\text { S }\end{array}$ & 85.29 & $\begin{array}{c}\text { SBS } \\
\text { I }\end{array}$ & 79.76 & $\begin{array}{c}\text { VNC } \\
\text { S }\end{array}$ & 84.01 \\
\hline $\mathbf{2}$ & \multicolumn{7}{c|}{ KIS } & 79.52 & & \\
\hline \multicolumn{7}{|c|}{ Source: compiled from financial statements of member securities } \\
companies
\end{tabular}

of Ho Chi Minh Stock Exchange)

Overall, the system of securities companies in Vietnam has a secure ratio of receivables to total assets. In particular, there are still one or two companies that do not guarantee this ratio. This is also a good sign in ensuring financial safety of Vietnamese securities companies.

\section{Earnings Assessment (E)}

With the purpose of evaluating the earnings power of securities companies, the author uses the ratio of return on equity $(\mathrm{ROE})$ as a representative. ROE indicates the return on equity over a certain period of time, which is a vital criterion in persuading investors to become the shareholders. Normally, a high ROE shows that the return on equity of the securities company is high, the equity is used effectively and then the securities company can easily increase the size of equity to expand the business, contributing to financial safety. In general, in Vietnam market conditions, when ROE reaches $0 \%$ or more, the securities company's finances are considered secure. According to the evaluation criteria of securities companies in Decision No. 617/QD/UBCK dated ered to have good earnings power (reaching over 70 points), from $0 \%$ to $5 \%$ is normal (reaching 50 points) and below $0 \%$ is not good. From the statistics, ROE of Vietnamese securities company system is shown as below:

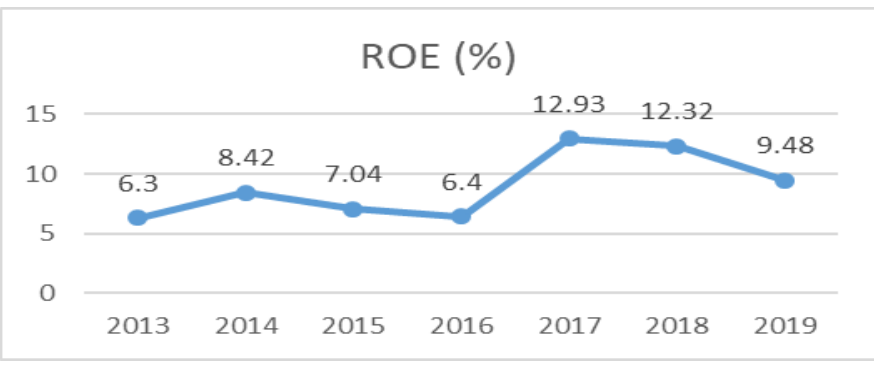

Figure 3. Return on equity of securities companies

(Source: compiled from financial statements of the member securities companies of Ho Chi Minh Stock Exchange)

For the whole period of 2013-2019, their average ROE has reached over 5\%, of which the highest was in 2017 and ROE was over $12 \%$ in 2018. 2017 was the year when the Vietnamese stock market developed strongly because of favorable factors from the macro-economic environment and the introduction of the derivatives stock market also helped the underlying stock market to operate more vibrantly and positively. That was also the reason for securities companies to increase their earnings power and reach a high level in 2017 and continue in 2018. Typically, the top 10 securities companies with ROE over 5\% from 2013 to 2019 can be mentioned as in Table 3 below:

TABle 3. ROE of 10 SeCURITIES COMPANiES AT OVER 5\% IN THE WHOLE PERIOD OF 2013-2019

\begin{tabular}{|ccccccccc|}
\hline No. & SC & $\mathbf{2 0 1 3}$ & $\mathbf{2 0 1 4}$ & $\mathbf{2 0 1 5}$ & $\mathbf{2 0 1 6}$ & $\mathbf{2 0 1 7}$ & $\mathbf{2 0 1 8}$ & $\mathbf{2 0 1 9}$ \\
\hline $\mathbf{1}$ & FPTS & $7.87 \%$ & $11.17 \%$ & $10.14 \%$ & $10.57 \%$ & $12.00 \%$ & $27.78 \%$ & $10.49 \%$ \\
\hline $\mathbf{2}$ & HSC & $12.80 \%$ & $16.33 \%$ & $9.20 \%$ & $13.04 \%$ & $21.38 \%$ & $23.09 \%$ & $32.03 \%$ \\
\hline $\mathbf{3}$ & IBSC & $14.70 \%$ & $22.71 \%$ & $12.72 \%$ & $6.87 \%$ & $9.09 \%$ & $21.35 \%$ & $9.22 \%$ \\
\hline $\mathbf{4}$ & SSI & $8.00 \%$ & $13.62 \%$ & $13.78 \%$ & $12.68 \%$ & $14.73 \%$ & $14.66 \%$ & $9.8 \%$ \\
\hline $\mathbf{5}$ & TCBS & $21.97 \%$ & $17.00 \%$ & $30.30 \%$ & $27.74 \%$ & $32.39 \%$ & $42.91 \%$ & $37.62 \%$ \\
\hline $\mathbf{6}$ & VCBS & $7.85 \%$ & $9.80 \%$ & $6.84 \%$ & $5.95 \%$ & $12.60 \%$ & $12.76 \%$ & $10.25 \%$ \\
\hline $\mathbf{7}$ & VCSC & $13.73 \%$ & $22.79 \%$ & $29.36 \%$ & $31.04 \%$ & $30.50 \%$ & $24.69 \%$ & $18.02 \%$ \\
\hline $\mathbf{8}$ & VNDS & $10.82 \%$ & $10.38 \%$ & $9.64 \%$ & $9.59 \%$ & $21.19 \%$ & $13.59 \%$ & $12.27 \%$ \\
\hline $\mathbf{9}$ & TVSC & $15.55 \%$ & $16.01 \%$ & $16.43 \%$ & $11.30 \%$ & $24.82 \%$ & $17.37 \%$ & $11.89 \%$ \\
\hline $\mathbf{1 0}$ & CTS & $7.29 \%$ & $7.28 \%$ & $8.00 \%$ & $8.06 \%$ & $9.81 \%$ & $12.10 \%$ & $8.74 \%$ \\
\hline
\end{tabular}

(Source: compiled from financial statements of the member securities companies of Ho Chi Minh Stock Exchange)

These companies always reach an above 5\% ROE though the years in the period shown. This proves that the return on equity of these securities companies is very stable and high. Technological and Commercial Securities (TCBS) is on top with ROE of $42.91 \%$ and $37.62 \%$ in 2018 and 2019 respectively, followed by Viet Capital Securities Company (VCSC) with ROE of $31.04 \%$ in 2016 and 30.5\% in 2017. Therein, there was a significant increase to $104 \%$ in the brokerage revenue in 2018. FPTS Securities also achieved a fairly high ROE in 2018 at $27.78 \%$.

According to international standards, ROE of $15 \%$ or more is most likely considered safe. Compared to this figure, the ROE of the whole industry has not been achieved. There are only a few securities firms in the market that have 
seen this high safe ratio. In 2013, the whole market had only 3 securities companies with ROE $>15 \%$, in 2014 there was 8. A slight decrease from 5 to 4 in the number of companies achieving ROE ratio $>15 \%$ was recorded in the period from 2015 to 2016. Between 2017 and 2019, the figures were 6, 4 and 2 respectively. Several securities companies always maintain a high ROE ratio such as VCSC, TCBS, TVSC... These are large companies with good risk management ability followed by high profitability.

In contrast, there are still many securities companies with low or negative ROE in consecutive years.

TABLE 4. ROE OF SOME SECURITIES COMPANIES HAS BEEN NEGATIVE FOR MANY YEARS UNIT: \%

\begin{tabular}{|c|c|c|c|c|c|c|c|c|}
\hline No. & SC & 2013 & 2014 & 2015 & 2016 & 2017 & 2018 & 2019 \\
\hline 1 & APSC & -7.43 & 2.04 & -7.81 & -10.75 & -1.27 & -13.49 & -10.76 \\
\hline 2 & JSI & 2.53 & -7.51 & -9.27 & -13.37 & -1.41 & 0.69 & 5.84 \\
\hline 3 & GMC & -8.84 & -28.53 & 7.62 & -2.64 & -3.46 & 0.65 & 0.20 \\
\hline 4 & VGW & -35.15 & -32.08 & 8.15 & 20.78 & -5.11 & -38.58 & -19.35 \\
\hline 5 & VNCS & -9.28 & 3.16 & -0.81 & -18.05 & -19.45 & 5.23 & 0.21 \\
\hline 6 & VSC & 1.14 & 0.67 & -2.47 & -3.86 & -2.16 & 3.24 & -8.08 \\
\hline 7 & VTSS & -3.80 & -6.51 & -7.56 & -9.95 & 0.12 & 0.04 & 0.05 \\
\hline 8 & DAS & -5.95 & -49.23 & -33.70 & 5.24 & -2.45 & -0.74 & 0.09 \\
\hline 9 & SBBS & -1.51 & -1.20 & -2.83 & -2.42 & -1.52 & -122.14 & -10.85 \\
\hline 10 & SSV & -0.97 & -3.84 & -5.94 & -10.37 & -3.19 & 6.46 & 6.79 \\
\hline
\end{tabular}

From the statistics, it can be inferred that there are many securities companies with ROE $<0$ for many years ( 4 years or more). The saddest thing is that SBBS (Saigonbank-Berjaya Securities Joint Stock Company) has ROE $<0$ in the whole period from 2013 to 2019, even ROE in 2018 is $122.14 \%$, an alarming number in terms of earnings power of this company. This is owing to the fact that the company's management costs are quite large (accounting for nearly half of the total expenses), even in 2018, this expense spiked more than 16 times compared to 2017. Meanwhile, the company's operating revenue is not sufficient to cover costs, typically the continuous losses from its brokerage activities have been recorded over the years, of which the revenue is always lower than brokerage operating expenses. Besides, there are also securities companies with ROE $<0$ for 5 consecutive years such as APSC (ALPHA Securities Joint Stock Company) and SSV (Shinhan Securities Vietnam Co., LTD). However, SSV has made a highly positive change in enhancing ROE in 2018 and it occupied over $6 \%$ in the next year. It is for the reason that SSV's NPAT increased from 14.7 billion to 52.5 billion in 2018 and 58.9 billion in 2019 . Thus, 2018's NPAT increased by $457 \%$ compared to 2017 , which is due to the increase in net revenue from 8.8 billion in 2017 to 88.8 billion in 2018 (by 909\%). In which, the company's revenue mainly comes from the profit from financial assets at fair value through profit or loss (FVTPL) including dividends, profit arising from financial assets at FVTPL and profit from held-to-maturity securities (HTM); additionally, consulting activities also brought fairly high revenue for the company over the past 2 years, which was free or very low in previous years. It is concluded that the effort to increase net revenue has greatly improved and enhanced the business efficiency of the company.

\section{Assess Liquidity Quality (L)}

The criterion that represents the liquidity of securities companies selected is the short-term solvency ratio (the ratio of short-term assets to short-term liabilities). The short-term solvency ratios of Vietnamese securities firms are as follows:

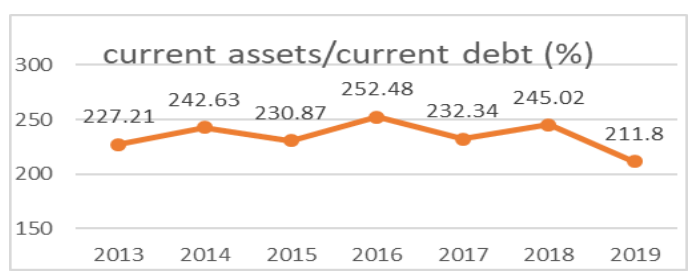

Figure 4. Current assets to current debt ratio of securities companies (Source: compiled from financial statements of the member securities companies of Ho Chi Minh Stock Exchange)

From the statistics, the short-term solvency ratio of the Vietnamese securities company system is always much higher than the safety threshold (120\%). However, this ratio has changed over the years and decreased the most in 2019. Therefore, in the coming time, securities companies need to regularly manage current assets as well as current liabilities to avoid a decline below the safe threshold.

Most securities companies in the market meet the requirements of this indicator, only Phuong Dong Securities Joint Stock Company (ORS) has not achieved the safety threshold until $2016(116.9 \%)$. This is also a securities company that has suffered losses for 3 consecutive years and is facing a high risk of losing financial safety.

According to international practice, the ratio of short-term assets to short-term liabilities must reach $200 \%$ or more to be considered safe. Accordingly, on average, only 8 securities companies did not achieve the safety level in 2016 but still did it in accordance with Vietnam's regulations.

Limitations that need to be overcome in ensuring financial safety of Vietnamese securities companies

In addition to the achieved results, in recent years, Vietnamese securities companies have still dealt with some shortcomings and limitations in the financial safety situation and supervision, specifically:

First, there is a clear difference between securities companies in terms of financial safety.

Considering the whole system of Vietnamese securities companies, most of the average finance criteria meet the required threshold. However, in the market, the number of securities companies currently operating normally and not meeting the safety thresholds of the criteria still accounts for a high proportion. It lacks consistent development in the system of the securities firms in the market, in other words, there is a clear differentiation among them. Most large securities companies are able to ensure highly secure finance, on the contrary, small firms always fall into the versa situation. Therefore, challenges and competitive pressure are increasingly weighing on small and medium sized securities companies. As a consequence, a weak and inefficient business will be eliminated. In the market economy, under the pressure of competition, it is inevitable that a weak and inefficient business will be removed. However, if that process happens suddenly on a large scale, it will cause highly seri- 
ous consequences, especially in the financial services sector in general and the securities sector in particular.

Second, some Vietnamese securities businesses have not met capital adequacy and asset quality.

The available capital ratio of some securities companies is lower than $180 \%$, not meeting the requirements of sufficient capital. The low ratio illustrates that the amount of available capital of the securities company is not enough to cover the total risk value including market risk, liquidity risk and operational risk. Thus, if these businesses do not propose any solutions to increase the rate of available capital and secure finance, they will be at risk.

Moreover, the receivable to total asset ratio of some securities firms is still high (over 75\%). It shows that the risk will be very high if it takes long to recover the receivables or they are converted into doubtful or irrecoverable debts. If these securities companies continue to finance customers at a high rate, there is a potential risk of losing finance safety.

Third, the earnings power of Vietnamese securities companies is still low.

The profitability of securities companies in the market has been improved significantly, but in general, it is still low and fluctuates quite erratically, depending mainly on the volatility of the stock market. Many businesses still suffer from long-term losses, deeply ingraining in the charter capital, leading to a decrease in equity. In comparison with other financial services such as banking, insurance, etc., securities trading is still a less efficient business with low ROE.

Fourth, there are still some securities companies that have not yet ensured liquidity quality.

A majority of securities companies ensure short-term debt solvency in the period from 2013 to 2019 , which is a relatively positive point for the market. However, there are still a few securities firms with low solvency, which can pose a risk to these businesses when brokerage activities take up a large proportion, depending on customer deposits as well as much debt use.

\section{ReCommendations}

\section{A. For securities companies}

First: Improving the financial capacity of securities
firms

Improving financial capacity aims to help securities com-
anies have strong financial potential, capital structure and asset structure suitable to the company's business operations. It also aims to maintain capital adequacy for securities companies according to the CAMEL safety framework. As reviewed above, some have not yet ensured the required ratio of available capital, which is usually calculated by subtracting illiquid asset value from the equity. Therefore, to increase the ratio of available capital, securities companies need to increase equity and reduce the value of illiquid assets, such as receivables (because some securities companies still have a fairly high ratio of receivables to total assets). Securities companies can increase equity by traditional methods such as issuing more shares; or increasing retained earnings for reinvestment, reducing annual dividends to shareholders; or increasing capital through business mergers and acquisitions. In order to reduce receivables, securities companies need to take drastic measures to collect receivables, especially bad debts. Furthermore, it is necessary to classify receivables into different groups: recoverable debts, doubtful debts and irrecoverable debts. Then, it is vital to give solutions to manage and monitor each debt group so that the firms quickly recover capital, avoid the risk of capital being appropriated for too long or the risk of losing capital due to non-recovery.

Second: Improving corporate governance and administration capacity

The capacity of corporate governance and management is a key factor in business performance, improving the competitiveness of securities companies in the market, thereby contributing to ensuring financial safety for securities companies. In essence, corporate governance and administration activities are aimed at achieving several goals such as increasing the company's value, monitoring and protecting the interests of the company's owners, protecting the interests of those related to the company as employees, partners, customers and creditors. In order to improve their corporate governance capacity, securities companies need to build their own appropriate governance model. The reality shows that, there is no universal optimal governance model for all companies in each country, but each securities company in each country needs research and adjustment to build its own model suitable to the socio-economic development of the country and to the specific characteristics of the securities business. To do so, each company itself needs to plan corporate governance policies according to best practices, develop a training strategy and attract high-quality human resources, and qualified business administrators to participate in the management and administration of the company. The strategy for training and attracting labor force should be developed to ensure a professional, stable and friendly working environment; professional ethical principles are established and promoted; having an appropriate income mechanism on the principle of being consistent with the quality and efficiency of completed work; there is an appropriate mechanism to expand income from the company's high business performance and the efficiency of completing the assigned work higher than as expected, such as the mechanism of selling shares at a preferential price for employees or bonus in cash, bonus in shares; ...

Third: Strengthening risk management at securities companies

The world financial crisis and its impact on Vietnam's stock market have left many valuable lessons for Vietnamese securities companies about the importance of risk management. Some securities companies got caught up in proprietary trading and securities lending, then suffering huge losses from investment and doubtful receivables that were no longer recoverable, typically in the case of Sacombank Securities Joint Stock Company (SBS) and Thang Long Securities Joint Stock Company (now MBS). Therefore, it is necessary for securities companies to strengthen risk management in order to detect and limit risks that have not yet occurred, and at the same time to minimize damage caused by risks, thereby contributing to ensuring financial safety. In order for risk management to be carried out effectively, securities companies must meet the following condi- 
tions: Firstly, build a risk management apparatus; Second, establish and issue a risk policy; Third, develop and implement internal processes related to risk management activities that meet the following principles: Identify, measure, monitor, report and treat material risks in an appropriate manner; Ensure independent, objective, honest and consistent operation; Separate the risk management department and staff from the operational department, the person in charge of the risk management department is not concurrently with the operational department and vice versa.

Fourth, improving the earnings power of securities companies

According to the analysis above, the profitability of some securities companies is still low, even the loss of business activities lasts for many years, leading to the inability to secure finance because the capital source is gradually eroded. Therefore, securities companies need to propose solutions to improve profitability through good management of the company's revenues and expenses. Securities companies need to develop their strong activities to expand market share and increase revenue. For large securities firms with strong financial potential and ability to meet the regulations on legal capital in performing business operations, it is advisable to diversify business activities, including brokerage and investment, consulting, self-trading and securities underwriting. For securities companies with small capital scale, which do not meet the requirements for capital allocated to carry out guarantee activities (minimum charter capital is 165 billion VND), they can find their own direction by specializing in brokerage and consulting services to increase revenue. In addition, in order to best serve the customers' increasing demands, securities companies must constantly improve service quality, modern technology systems, help investors make quick, convenient and safe transactions. The staff of the Securities Company must also be highly qualified and professional, having sufficient practice certificates as prescribed and good professional ethics in order to meet the customers' needs. In addition to finding solutions to increase revenue, securities companies must also manage expenses well, including costs for securities company operations and corporate management costs. Many companies have high turnover but poor cost management leading to low or even no profit. Therefore, it is important to review expenses and have specific solutions to use them economically and effectively.

\section{B. For state management agencies}

Firstly, constantly promoting the restructuring of securities companies

It is the fact that the number of Vietnamese securities companies is too high compared to the size of the Vietnamese stock market, which results in fierce competition among securities companies; it is increasingly difficult for small-sized securities companies to exist with a potential risk of losing financial safety, thereby affecting system safety. Therefore, the State Securities Commission still needs to continuously promote the restructuring of Vietnam's securities companies in the direction of decreasing in quantity but increasing in quality, ensuring safety in the operation of securities companies and the entire stock market.
Second, strengthening financial safety supervision for securities companies

In order for the supervision of financial safety of Vietnamese securities companies to be effective, it is vital to enhance the supervisory capacity of the management agencies so that they have ability to supervise financial safety of securities companies, and simultaneously, it is necessary to constantly improve the set of criteria for assessing financial safety of securities companies in Vietnam and study and apply the system of standards for assessing financial safety of securities companies in accordance with international practices.

Third, assisting in improving the personnel's quality and professional ethics in the securities industry

Currently, securities companies are experiencing the shortage of high-quality personnel in business management and risk management, so it is necessary for specialized management agencies to contribute to training, building and completing training programs to improve corporate governance capacity and risk management capacity for securities companies.

Fourth, constantly improving the principles and legal framework for the stock market

It is essential to regularly improve the principles and legal framework to promote the stock market to develop extensively, in the direction of transparency and synchronization, ensuring the rights and interests of market participants and in accordance with the international standards; completing the principles and legal framework on the stock market in order to fully institutionalize the views and policies of the Party and the State, simultaneously in accordance with the socio-economic development conditions of the country, selectively absorbing international experiences to form a synchronous and unified stock market system in the overall financial market.

\section{REFERENCES}

[1] Haseeb Zaman Babar và Gul Zeb, "Camels Rating System for Banking industry in Pakistan," 2011

[2] Hoang Thi Bich Ha, "Financial Safety of Vietnamese securities companies," doctoral thesis in economics of Academy of Finance, 2018.

[3] IOSCO, "Capital Adequacy Standards for securities firms," 1989.

[4] IOSCO, "Comparison of Equity Position Risk And Scope For Harmonization," 1990.

[5] Ministry of Finance, "Circular stipulating financial safety norms and handling measures for securities trading organizations that fail to meet the financial safety criteria," Circular No. 91/2020/TT-BTC dated $13 / 11 / 2020$.

[6] Misha Aswini Kumar, G.SriHasha, Shivi Anand và Neil Rajesh Dhuva, "Analyzing Soundness in Indian Banking: A Camel Approad," 2012.

[7] Nguyen Thanh Phuong, "Financial Safety of Vietnamese securities companies." Scientific research project at the Academy level, Banking Academy, 2016

[8] Philip L.Brock, "Financial Safety Nets and Incentive Structures in Latin America," 1999.

[9] State Securities Commission, "Decision on promulgating the regulation guiding the classification of securities companies", Decision No. 617/QD-UBCK dated October 9, 2013.

[10] Tran Thi Xuan Anh, "Application of the CAMEL system to evaluate the performance of Vietnamese securities companies," Research project, Banking Academy, 2014.

[11] Truong Van Gioi - Le Khac Kieu Luc, "Sino-Vietnamese dictionary," Social Science Publisher, 2010.

[12] Wirnkar và Tanko, "Camels and Banks Performance Evaluation: The way Forward,” 2008. 
Appendix: Criteria, scale and weight of key factors in ranking

\begin{tabular}{|c|c|c|c|c|c|}
\hline No. & Criteria & Value & Value & Score & Weight \\
\hline \multicolumn{6}{|c|}{ Capital Adequacy } \\
\hline \multirow{3}{*}{1} & \multirow{3}{*}{$C_{1}-$ Equity/Total Assets } & From $0 \%$ & To less than $51 \%$ & 20 & \multirow{3}{*}{$10 \%$} \\
\hline & & From 51\% & To less than $75 \%$ & 80 & \\
\hline & & From $75 \%$ or more & & 100 & \\
\hline \multirow{5}{*}{2} & \multirow{5}{*}{$\mathrm{C}_{2}$ - Equity/Legal Capital } & & Less than $60 \%$ & 0 & \multirow{5}{*}{$10 \%$} \\
\hline & & From $60 \%$ & To less than $100 \%$ & 30 & \\
\hline & & From $100 \%$ & To less than $150 \%$ & 60 & \\
\hline & & From $150 \%$ & To less than $200 \%$ & 80 & \\
\hline & & From $200 \%$ or more & & 100 & \\
\hline \multirow{5}{*}{3} & \multirow{5}{*}{$\mathrm{C}_{3}$ - Available Capital Ratio } & & Less than $120 \%$ & 0 & \multirow{5}{*}{$10 \%$} \\
\hline & & From $120 \%$ & To less than $150 \%$ & 20 & \\
\hline & & From $150 \%$ & To less than $180 \%$ & 40 & \\
\hline & & From $180 \%$ & To less than $300 \%$ & 80 & \\
\hline & & From $300 \%$ or more & & 100 & \\
\hline \multicolumn{6}{|c|}{ Asset quality } \\
\hline \multirow{5}{*}{4} & \multirow{5}{*}{$\begin{array}{l}\mathrm{A}_{1}-\text { Ratio of risk-adjusted } \\
\text { assets/total assets (excluding } \\
\text { fixed assets) }\end{array}$} & & Less than $50 \%$ & 0 & \multirow{5}{*}{$5 \%$} \\
\hline & & From $50 \%$ & To less than $65 \%$ & 20 & \\
\hline & & From $65 \%$ & To less than $80 \%$ & 50 & \\
\hline & & From $80 \%$ & То $90 \%$ & 80 & \\
\hline & & From $90 \%$ or more & & 100 & \\
\hline \multirow{5}{*}{5} & \multirow{5}{*}{$\begin{array}{l}\mathrm{A}_{2}-\text { Ratio of Provision/(short- } \\
\text { term investments + long-term } \\
\text { investments + receivables) }\end{array}$} & From $10 \%$ or more & & 0 & \multirow{5}{*}{$10 \%$} \\
\hline & & From $8 \%$ & To less than $10 \%$ & 20 & \\
\hline & & From 5\% & To less than $8 \%$ & 50 & \\
\hline & & Above $0 \%$ & To less than $5 \%$ & 80 & \\
\hline & & 0 & & 100 & \\
\hline \multirow{5}{*}{6} & \multirow{5}{*}{$\begin{array}{l}\mathrm{A}_{3} \text {-Receivables/Total assets } \\
\text { ratio }\end{array}$} & From $90 \%$ or more & & 0 & \multirow{5}{*}{$10 \%$} \\
\hline & & From $75 \%$ & to $90 \%$ & 20 & \\
\hline & & From $50 \%$ & to $75 \%$ & 50 & \\
\hline & & From $25 \%$ & to $50 \%$ & 80 & \\
\hline & & & Less than $25 \%$ & 100 & \\
\hline \multicolumn{6}{|c|}{ Earnings power } \\
\hline \multirow{5}{*}{7} & & & Nhỏ hơn $-10 \%$ & 0 & \\
\hline & & From $-10 \%$ & To less than $0 \%$ & 20 & \\
\hline & $\begin{array}{l}\mathrm{E}_{1}-\text { Profit after tax/lotal } \\
\text { revenue }\end{array}$ & From $0 \%$ & To less than $5 \%$ & 50 & $10 \%$ \\
\hline & & From 5\% & To less than $20 \%$ & 70 & \\
\hline & & From $20 \%$ or more & & 100 & \\
\hline & & & Less than $-5 \%$ & 0 & \\
\hline & & From $-5 \%$ & To less than $0 \%$ & 20 & \\
\hline 8 & $\mathrm{E}_{2}$ - Profit after tax/Average & From $0 \%$ & To less than $5 \%$ & 50 & $10 \%$ \\
\hline & & From 5\% & To less than $25 \%$ & 70 & \\
\hline & & From $25 \%$ or more & & 100 & \\
\hline Liquid & lity & & & & \\
\hline & & & To less than $100 \%$ & 0 & \\
\hline 0 & $\mathrm{~L}_{1}$ - Current Assets/Current & From $100 \%$ & To less than $120 \%$ & 40 & $15 \%$ \\
\hline 9 & Liabilities & From $120 \%$ & To less than $150 \%$ & 80 & $15 \%$ \\
\hline & & From $150 \%$ or more & & 100 & \\
\hline 10 & $\begin{array}{l}\mathrm{L}_{2}-\text { Ratio of cash and cash } \\
\text { equivalents/Current debt }\end{array}$ & & To less than $10 \%$ & 0 & $10 \%$ \\
\hline
\end{tabular}

(Excerpt from Appendix 01 issued together with Decision No. 617/QD/UBCK dated October 9, 2013) 